\title{
Factors Influencing E-Procurement on the Implementation of Public Institution in Rwanda: A Case of Kigali City (2014-2016)
}

\section{| Gedion Alang'o Omwono ${ }^{1, *}$ | Sazir Nsubuga Mayanja² | | Karekezi Rodrigue ${ }^{3}$ |}

${ }^{1,2}$ Department of Business Management and Economics, University of Kigali, Kigali City, Rwanda

${ }^{3}$ Master of Science in procurement and Supply Chain Management, University of Kigali, Rwanda *gedion.impact@gmail.com

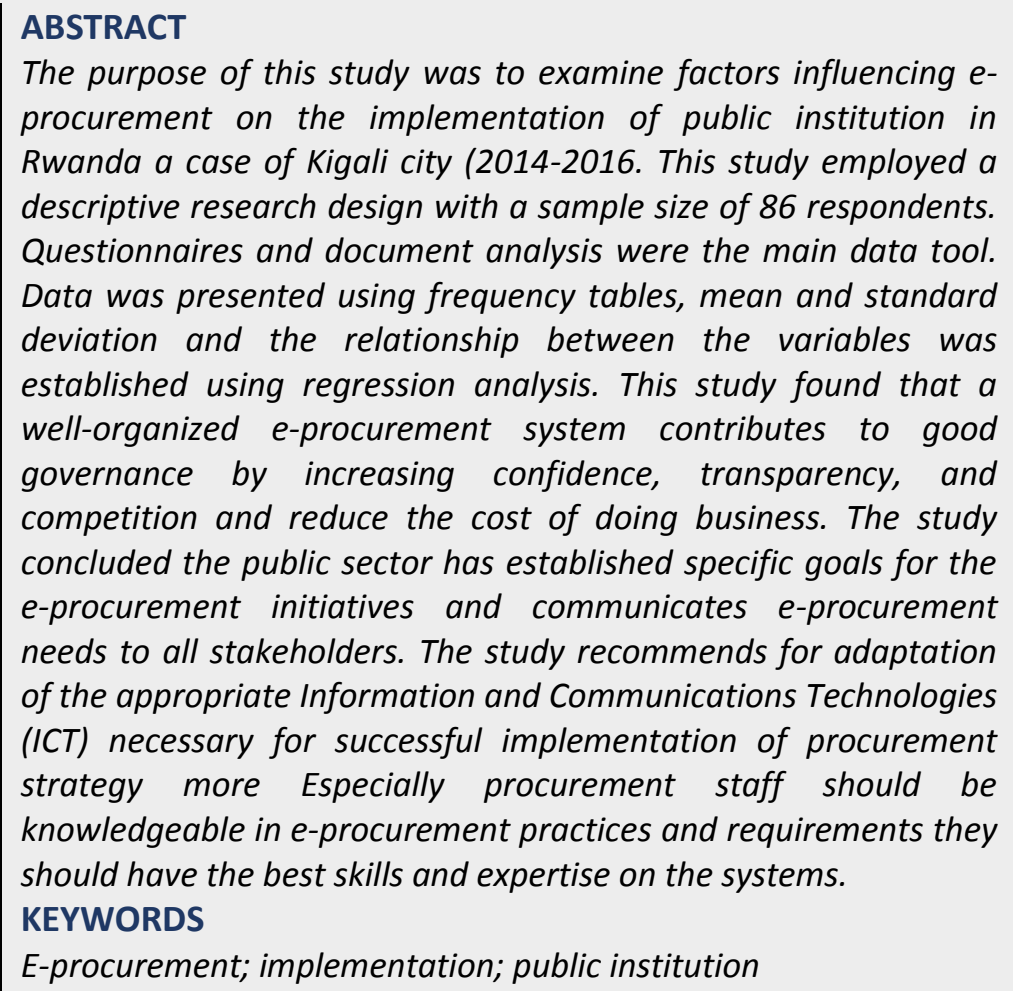
procurement on the implementation of public institution in Rwanda a case of Kigali city (2014-2016. This study employed a descriptive research design with a sample size of 86 respondents. Questionnaires and document analysis were the main data tool. Data was presented using frequency tables, mean and standard deviation and the relationship between the variables was established using regression analysis. This study found that a well-organized e-procurement system contributes to good governance by increasing confidence, transparency, and competition and reduce the cost of doing business. The study concluded the public sector has established specific goals for the e-procurement initiatives and communicates e-procurement needs to all stakeholders. The study recommends for adaptation of the appropriate Information and Communications Technologies (ICT) necessary for successful implementation of procurement strategy more Especially procurement staff should be knowledgeable in e-procurement practices and requirements they should have the best skills and expertise on the systems. KEYWORDS

E-procurement; implementation; public institution

\section{INTRODUCTION}

E-procurement refers to the use of internet-based (integrated) Information and Communication Technologies (ICT) to carry out individual or all stages of the procurement process including search, sourcing, negotiation, ordering, receipt, and post purchase review (Croom \& Brandon-Jones, 2004).

Ideally, e-tendering platform is a web-based, collaborative system to facilitate the full lifecycle of a tendering process, for both buyers and suppliers. It offers a secure, interactive, dynamic environment for procurements of any nature, complexity or value, enforcing and encouraging recognized best practices. E-PPS supports the process of procuring works, services and supplies electronically.

However, in Rwanda, there is lack of perceived benefits of e-procurement by many stakeholders who participate in the transactions. This is due to lack of professionalism and enough skills in ICT which in turn make reluctance in going for this modern way of procurement despite the fact that some of the activities like advertisement of tendering is currently done through internet.

Various studies have been done in this area of e-procurement. In a study by Luvuyu, M.M., (2013) on factors affecting adoption of e-procurement technologies from suppliers point of view, it was found that the e-procurement adoption is driven by internal needs. Adoption 
also reduces labor costs, and improves customer relations. In yet another study by Abagna, J. A \& Akay,E,. (2015) on prospects and challenges of E-Procurement in some selected Public Institutions in Ghana it found that employee competency, inadequate legal framework, inadequate technological infrastructure and security of procurement transaction data were challenges to e-procurement adoption in the organizations under review. However, in a study done by Ochieng', E.,O (2016) on role of e-procurement performance in state corporations in Kenya it was found that state corporations have adopted e-tendering, e-award, e-ordering and e-invoicing to some extent in order to enhance their procurement performance.

No study has been done to address the above-mentioned problems in Rwanda despite it having knowledge related to e-procurement, especially given that Rwandese government. This study therefore examines factors influencing e-procurement implementation in public institution in Rwanda.

The general objective of this study is to investigate the factors influencing the implementation of e-procurement in the public institution with a focus on the City of Kigali. The main purpose of the study are:

- To examine the factors of e-procurement within Kigali City.

- To examine how the staff training influences implementation of e-procurement in the in the City of Kigali.

- To establish the influence of information technology infrastructure on implementation of e-procurement in the City of Kigali.

- To determine the influence of supplier performance on implementation of eprocurement in the City of Kigali.

\section{RESEARCH METHODS}

This study employed a descriptive research design to assess the factors influencing implementation of e-procurement and performance in the city of Kigali.

The targeted population under this study were 110 of which 60 are bidders according to Kigali City report (2017)

Under this study, non -probability sampling was applied where 86 respondents were sampled as illustrated below.

Table 1. Sample size

\begin{tabular}{|c|c|c|c|c|c|}
\hline Strata (Sector) & $\begin{array}{l}\text { No. of } \\
\text { staff }\end{array}$ & $\begin{array}{l}\text { Proportional } \\
\text { Percentage }\end{array}$ & & Sample size & Justification \\
\hline Procurement & 8 & 7.3 & & 8 & Purposive \\
\hline Finance & 7 & 6.4 & $D$ & 7 & Purposive \\
\hline HR and Admin & 5 & 4.5 & $=$ & 5 & Purposive \\
\hline Corporate Affairs & 6 & 5.5 & हิ & 6 & Purposive \\
\hline Administration Staff & 24 & 21.8 & ะี อิ & 12 & Convenient \\
\hline Bidders & 60 & 54.5 & z & 48 & Convenient \\
\hline Total & 110 & 100 & & 86 & \\
\hline
\end{tabular}

Source: Author (2018)

\section{Data Collection Methods}

The data was collected by means of the questionnaires and document analysis under this study. The questionnaire was in form of both open-ended and closed-ended in nature and this was self-administered where the researcher was allowed to fill the questionnaire in the study field as per respondents' responses. 


\section{RESULT AND DISCUSSION}

\section{Respondents Rate}

The research intends to analyze and test the factors affecting e-procurement and implementation in public institutions. The data was collected using questionnaires which were distributed to 86 respondents and then after collecting their answers were analyzed using SPSS as a scientific tool for data analysis.

Socio-Demographic Characteristics of the Respondents

The study findings of socio-demographic characteristics (Gender, Age, Education and Experience) are summarized in the following tables.

Table 1. Age of respondents

\begin{tabular}{lccc}
\hline Age & Frequency & Percent & Cumulative Percent \\
\hline $31-40$ & 57 & 66.3 & 66.3 \\
$41-50$ & 29 & 33.7 & 100.0 \\
Total & 86 & 100.0 & \\
\hline
\end{tabular}

Source: Field data 2018

Table 1 shows that the majority $66.3 \%$ of the total respondents were aged between 31 40 while $33.7 \%$ of the total respondents were aged between 41-50. The researcher concludes that the respondents were mature and active people to contribute enough and implement the e-procurement of the Kigali city. People at this age are very energetic and this situation insures a strong contribution of employees on the routine activities of the eprocurement within Kigali city.

Table 2. Gender of Respondents

\begin{tabular}{lccc}
\hline Gender & Frequency & Percent & Cumulative Percent \\
\hline Male & 58 & 67.4 & 67.4 \\
Female & 28 & 32.6 & 100.0 \\
Total & 86 & 100.0 & \\
\hline
\end{tabular}

Source: Field data 2018

Table 2 shows that the majority $67.4 \%$ of the total respondents were Male while $32.6 \%$ of the total respondents were Female. The researcher concludes that the majority of the respondents which is male were highly participating in the e-procurement implementation within the Kigali city. Therefore the government needs to set strategies that should empower women in order to increase human capital through shared both male and female skills and knowledge.

Table 1. Marital Status of Respondents

\begin{tabular}{lccc}
\hline Marital Status & Frequency & Percent & Cumulative Percent \\
\hline Single & 28 & 32.6 & 32.6 \\
Married & 58 & 67.4 & 100.0 \\
Total & 86 & 100.0 & \\
\hline
\end{tabular}

Source: Field data 2018

Table 3 shows that the majority $67.4 \%$ of the total respondents were married while $32.6 \%$ of the total respondents were single. The researcher concludes that the majority of the respondents which is married were highly frequent to the e-procurement implementation within the Kigali city. This also shows that married people are stable and responsible rather than single. 
Table 4. Experience of Respondents

\begin{tabular}{lccc}
\hline Experience & Frequency & Percent & Cumulative Percent \\
\hline 4-6 years & 58 & 6.4 & 67.4 \\
7 years and above & 28 & 32.6 & 100.0 \\
Total & 86 & 100.0 & \\
\hline
\end{tabular}

Source: Field Data 2018

Table 4 demonstrates that the majority $67.4 \%$ of the total respondents have a working experience between 4-6 years while $32.6 \%$ of the total respondents have been working within Kigali City for a period which is 7 years and above. This shows that experienced employees can be fruitful to the organization. It implies that, the employees contribute greatly in the e-procurement implementation due to their experience and hence the organization equips them for achieving their duties and responsibilities.

Table 2. Education of Respondents

\begin{tabular}{lccc}
\hline Education & Frequency & Percent & Cumulative Percent \\
\hline Bachelor & 28 & 32.6 & 32.6 \\
Masters & 58 & 67.4 & 100.0 \\
Total & 86 & 100.0 & \\
\hline
\end{tabular}

Source: Field data 2018

Table 5 indicates that the majority of $67.4 \%$ from the total respondents were master's holders while $32.6 \%$ of the total respondents were bachelor's holder. This shows that the employees of the Kigali City are highly qualified which is meaningful in implementing eprocurement at Kigali city. Qualified employees may boost the knowledge regarding the implementation of the e-procurement.

Table 3. Working Departments of the Rrespondents

\begin{tabular}{lccc}
\hline Departement & Frequency & Percent & Cumulative Percent \\
\hline Operations & 29 & 33.7 & 33.7 \\
Procurement \& Bidders & 57 & 66.3 & 100.0 \\
Total & 86 & 100.0 & \\
\hline
\end{tabular}

Source: Field data 2018

Table 6 indicates that the majority $66.3 \%$ of the total respondents were employees working in the department of procurement while $33.7 \%$ of the total respondents were working in the department of operations. This shows these employees of the Kigali City are in right position of providing good answers on the implementation of e-procurement within Kigali city.

\section{E-Procurement and Implementation within Kigali City}

Implementing e-procurement can result in a high return and greater efficiencies, better visibility, more cost savings and companies fail to implement e-procurement effectively and they end up wasting time, resources, and money.

Factors Influencing E-procurement Implementation

Among the factors influencing e-procurement, using the IT, the e-Procurement system is technically specified in detail and speedy. On the other hand, interfaces and security requirements are specified in detail. The problem statement, goals, specification and procurement process is described in a tender document which is distributed to eProcurement suppliers (on the long-list). Supply Value has tender document and presentation templates available which saves much time in this phase. 
Table 4. Factors Influencing E-Procurement Implementation within Kigali City

\begin{tabular}{|l|r|r|r|r|r|}
\hline Statements & N & $\begin{array}{r}\text { Mini } \\
\text { mum }\end{array}$ & $\begin{array}{c}\text { Maxi } \\
\text { mum }\end{array}$ & Mean & $\begin{array}{c}\text { Std. } \\
\text { Deviation }\end{array}$ \\
\hline The size of the firm & 86 & 4.00 & 5.00 & 4.3372 & .87553 \\
The management support & 86 & 4.00 & 5.00 & 4.3372 & .87553 \\
The level of Government support & 86 & 4.00 & 5.00 & 4.3256 & .77134 \\
Ability to link directly to existing systems & 86 & 2.00 & 5.00 & 4.0233 & .61402 \\
Financial Resources available & 86 & 4.00 & 5.00 & 4.6628 & .97568 \\
The top management support & 86 & 4.00 & 5.00 & 4.6628 & .97568 \\
Competitive pressure from competitors and & 86 & 4.00 & 5.00 & 4.3256 & .87553 \\
other stakeholders & & & & & \\
National IT infrastructure available to the firm & 86 & 4.00 & 5.00 & 4.3256 & .87553 \\
Valid N (listwise) & 86 & & & & \\
\hline Source: Field Data 2018
\end{tabular}

Source: Field Data 2018

Table 7 sought to determine the respondents` level of agreement or disagreement with the above statements relating to factors affecting e-procurement implementation within Kigali city, from the findings the majority of respondents views agreed and strongly agreed that financial Resources available; the top management support; Ability to link directly to existing systems; the level of Government support; the management support; the size of the firm; National IT infrastructure available to the firm and Competitive pressure from competitors and other stakeholders with the mean from 4.3256 to 4.6628 revealed extremely positive and the standard deviation varies from 0.61402 and 0.97568 which shows a positive relationship.

The researcher concludes that electronic procurement consists of leveraging the purchasing of goods and services using the internet. It is a vital aspect of any overall strategic procurement plan in today's business environment. It includes supply chain automation, strategic sourcing, and supplier rationalization. An electronic solution can significantly reduce cycle times and transaction costs by consolidating the procuring process across all departments, and thus, improve a company's bottom line. Automating the process can free up your time and allow you to better manage your relationships with suppliers in order to create ever-increasing velocity in your supply chain. It has a positive impact on ordering, inventory, returns, billing, and customer service. In the implementation phase the e-Procurement system is delivered in the realization of implemented into the organization and its processes.

\section{Management Supports}

The successful implementation of e-procurement strongly relies on the managerial skills and management support. It is easy to place blame on upper management for lack of support to the implementation of e-procurement and this is a crucial factors which can lead to a effective and efficient procurement.

Table 5. Management Supports on Influencing E-Procurement Implementation

\begin{tabular}{|c|c|c|c|c|c|}
\hline Statements & $\mathbf{N}$ & $\begin{array}{l}\text { Mini } \\
\text { mum }\end{array}$ & $\begin{array}{l}\text { Maxi } \\
\text { mum }\end{array}$ & Mean & $\begin{array}{l}\text { Std. } \\
\text { Deviation }\end{array}$ \\
\hline Development of a realistic and achievable road map & 86 & 4.00 & 5.00 & 4.6628 & 97553 \\
\hline $\begin{array}{l}\text { Develop a time-bound roadmap for e-procurement } \\
\text { implementation }\end{array}$ & 86 & 4.00 & 5.00 & 4.6628 & 97553 \\
\hline $\begin{array}{l}\text { Undertake an analysis of the current e-procurement } \\
\text { practices }\end{array}$ & 86 & 4.00 & 5.00 & 4.6744 & 97934 \\
\hline
\end{tabular}




\begin{tabular}{|c|c|c|c|c|c|}
\hline $\begin{array}{l}\text { Technical solutions on the e-procurement } \\
\text { implementation }\end{array}$ & 86 & 2.00 & 5.00 & 3.9884 & 62659 \\
\hline $\begin{array}{l}\text { Assess financial risks associated with transaction } \\
\text { fee based models as they are only viable with the } \\
\text { right combination of volumes of procurement } \\
\text { transactions and affordable levels of fees }\end{array}$ & 86 & 4.00 & 5.00 & 4.6744 & 97934 \\
\hline $\begin{array}{l}\text { Support the Government of Rwanda's efforts to } \\
\text { develop online procurement }\end{array}$ & 86 & 4.00 & 5.00 & 4.6744 & 97934 \\
\hline $\begin{array}{l}\text { Work with tried and tested e-procurement vendors } \\
\text { with a proven track record and established } \\
\text { technology }\end{array}$ & 86 & 4.00 & 5.00 & 4.3372 & 87553 \\
\hline Apply a comprehensive e-procurement Strategy & 86 & 4.00 & 5.00 & 4.3256 & 87134 \\
\hline $\begin{array}{l}\text { Implementation of a simple e-notification and e- } \\
\text { tendering system and a separate procurement } \\
\text { management information system }\end{array}$ & 86 & 4.00 & 5.00 & 4.3256 & 87134 \\
\hline $\begin{array}{l}\text { Monitoring and achievable e-procurement using the } \\
\text { existing IT systems } \\
\text { Valid N (listwise) }\end{array}$ & 86 & 4.00 & 5.00 & 4.6628 & 97553 \\
\hline
\end{tabular}

Source: Field Data 2018

Table 8 sought to determine the respondents` level of agreement or disagreement with the above statements relating to top management support as factors affecting eprocurement implementation within Kigali city, from the findings majority of the respondents were strongly and agree that Support the Government of Rwanda's efforts to develop online procurement; Undertake an analysis of the current e-procurement practices; Assess financial risks associated with transaction fee based models as they are only viable with the right combination of volumes of procurement transactions and affordable levels of fees; Develop a time-bound roadmap for e-procurement implementation; Development of a realistic and achievable road map; Monitoring and achievable e-procurement using the existing IT systems; Work with tried and tested e-procurement vendors with a proven track record and established technology; Implementation of a simple e-notification and etendering system and a separate procurement management information system and Apply a comprehensive e-procurement Strategy with the mean varies from 4.3256 to 4.6628 revealed extremely positive and the standard deviation varies from 0.87134 and 0.97934 which shows a positive relationship and a strong concentration among the respondents. On the other hand Technical solutions on the e-procurement implementation with the mean of 3.9884 revealed positive and standard deviation of 0.62659 which shows a positive relationship.

The researcher concludes that management input on the course of action is not enough to implement but also needs the staff commitment in the implementation of e-procurement. In line with the interviewer which agreed with the findings that management support provides the orientation on the implementation of e-procurement as well as they help on increasing the skills to succeed; the organization must procure middle-management support who should work hand in hand with the top management during the e-procurement implementation.

\section{Staff training in Influencing E-procurement Implementation}

Training presents a prime opportunity to expand the knowledge base of all employees, but many employers in the current climate find development opportunities expensive. Employees attending training sessions also miss out on work time which may delay the completion of projects. However despite these potential drawbacks, training and 
development provides both the individual and organizations as a whole with benefits that make the cost and time a worthwhile investment.

Table 6. Staff Training on Influencing E-procurement Implementation

\begin{tabular}{|c|c|c|c|c|c|}
\hline Statements & $\mathbf{N}$ & $\begin{array}{l}\text { Mini } \\
\text { mum }\end{array}$ & $\begin{array}{l}\text { Maxi } \\
\text { mum }\end{array}$ & Mean & $\begin{array}{c}\text { Std. } \\
\text { Deviation }\end{array}$ \\
\hline $\begin{array}{l}\text { Ability to short list using supplier sourcing } \\
\text { information and performance }\end{array}$ & 86 & 4.00 & 5.00 & 4.3372 & .87582 \\
\hline $\begin{array}{l}\text { Increased confidence in supplier selection by } \\
\text { procurement personnel }\end{array}$ & 86 & 4.00 & 5.00 & 4.6628 & .97553 \\
\hline $\begin{array}{l}\text { Reduction in the number of complaints and protests } \\
\text { submitted to the Independent Procurement Review } \\
\text { Panel }\end{array}$ & 86 & 4.00 & 5.00 & 4.3372 & .87582 \\
\hline $\begin{array}{l}\text { Provide visibility on the overdependence of } \\
\text { suppliers or to track unusual procurement patterns } \\
\text { that require investigation }\end{array}$ & 86 & 4.00 & 5.00 & 4.6628 & .97553 \\
\hline $\begin{array}{l}\text { Reduction in the time it takes to prepare and } \\
\text { publish procurement notices and request for tenders }\end{array}$ & 86 & 4.00 & 5.00 & 4.3372 & .87582 \\
\hline Reduction in time taken to evaluate bids & 86 & 4.00 & 5.00 & 4.6744 & .97934 \\
\hline $\begin{array}{l}\text { Reduction in time taken for bidders to complete } \\
\text { and submit tenders }\end{array}$ & 86 & 4.00 & 5.00 & 4.3372 & .87582 \\
\hline $\begin{array}{l}\text { Improvements to procurement planning and } \\
\text { demand led intelligence }\end{array}$ & 86 & 4.00 & 5.00 & 4.3372 & .87582 \\
\hline $\begin{array}{l}\text { Improved knowledge capacity and capability of } \\
\text { procurement personnel }\end{array}$ & 86 & 4.00 & 5.00 & 4.3372 & .87582 \\
\hline $\begin{array}{l}\text { Reduction in time for the procurement life cycle } \\
\text { thereby resulting in a reduction in transaction costs }\end{array}$ & 86 & 4.00 & 5.00 & 4.3372 & .87582 \\
\hline Valid N (listwise) & 86 & & & & \\
\hline
\end{tabular}

Source: Field Data 2018

Table 9 sought to determine the respondents` level of agreement or disagreement with the above statements relating to top management support as factors affecting eprocurement implementation within Kigali city, from the findings majority of the respondents were strongly and agree that Ability to short list using supplier sourcing information and performance; Increased confidence in supplier selection by procurement personnel; Reduction in the number of complaints and protests submitted to the Independent Procurement Review Panel; Provide visibility on the overdependence of suppliers or to track unusual procurement patterns that require investigation; Reduction in the time it takes to prepare and publish procurement notices and request for tenders; Reduction in time taken to evaluate bids; Reduction in time taken for bidders to complete and submit tenders; Improvements to procurement planning and demand led intelligence; Improved knowledge capacity and capability of procurement personnel and Reduction in time for the procurement life cycle thereby resulting in a reduction in transaction costs with the mean varies from 4.3372 to 4.6744 revealed extremely positive and the standard deviation varies from 0.87582 and 0.97934 which shows a positive relationship and a strong concentration among the respondents.

The researcher concludes that staff training may improve employee performance the employee who receives the necessary training is more able to perform in their job. The training will give the employee a greater understanding of their responsibilities within their role, and in turn build their confidence. This confidence will enhance their overall performance and this can only benefit the company. Employees who are competent and on 
top of changing industry standards help your company hold a position as a leader and strong competitor within the industry.

It is in the same line that improved employee satisfaction and morale the investment in training that a company makes shows employees that they are valued. The training creates a supportive workplace. Employees may gain access to training they wouldn't have otherwise known about or sought out themselves. Employees who feel appreciated and challenged through training opportunities may feel more satisfaction toward their jobs.

Staff training addressing weaknesses most employees will have some weaknesses in their workplace skills. A training program allows you to strengthen those skills that each employee needs to improve. A development program brings all employees to a higher level so they all have similar skills and knowledge. This helps reduce any weak links within the company who rely heavily on others to complete basic work tasks. Providing the necessary training creates an overall knowledgeable staff with employees who can take over for one another as needed, work on teams or work independently without constant help and supervision from others.

\section{Information Technology on The E-procurement Transparency}

E-procurement, the aspect of e-business which addresses the relationships and processes of a business with its suppliers, was a hot topic for several years. Online marketplaces and reverse auctions were the main focus of interest. The procurement of an organization can significantly influence the success of a company. These days it operates in a dynamic, complex environment and in order to operate efficiently and effectively it has to create appropriate structures and make use of suitable instruments. Information technology can play an important role in this.

Table 10. Information Technology on Influencing E-procurement Implementation

\begin{tabular}{|c|c|c|c|c|c|}
\hline Statements & $\mathbf{N}$ & $\begin{array}{l}\text { Mini } \\
\text { mum }\end{array}$ & $\begin{array}{l}\text { Maxi } \\
\text { mum }\end{array}$ & Mean & $\begin{array}{c}\text { Std. } \\
\text { Deviation }\end{array}$ \\
\hline $\begin{array}{l}\text { Use of restricted and single source tendering } \\
\text { methods }\end{array}$ & 86 & 4.00 & 4.00 & 4.0000 & .88888 \\
\hline Increase customization online & 86 & 4.00 & 4.00 & 4.0000 & 88888 \\
\hline Increase customer convenience & 86 & 4.00 & 5.00 & 4.6744 & .97134 \\
\hline Request for proposals is done on time & 86 & 2.00 & 5.00 & 4.0233 & .88998 \\
\hline The procurement process is efficient & 86 & 4.00 & 5.00 & 4.6744 & .97134 \\
\hline $\begin{array}{l}\text { Ability to link directly to existing procurement } \\
\text { systems and transactions }\end{array}$ & 86 & 4.00 & 5.00 & 4.6628 & .97553 \\
\hline Easy and improved records management & 86 & 4.00 & 5.00 & 4.6628 & .97553 \\
\hline Transparency in the supply chain & 86 & 4.00 & 5.00 & 4.3256 & .97134 \\
\hline Easy authentication of suppliers & 86 & 5.00 & 5.00 & 5.0000 & 99999 \\
\hline $\begin{array}{l}\text { Adopt the most appropriate method and approach } \\
\text { for procuring the software }\end{array}$ & 86 & 5.00 & 5.00 & 5.0000 & 99999 \\
\hline $\begin{array}{l}\text { Ability to facilitate spend analysis i.e. who is } \\
\text { buying what, for how much, when and from whom, } \\
\text { through the commodity coding of all purchases }\end{array}$ & 86 & 5.00 & 5.00 & 5.0000 & 99999 \\
\hline $\begin{array}{l}\text { Sharing of performance information amongst } \\
\text { purchasing entities }\end{array}$ & 86 & 5.00 & 5.00 & 5.0000 & 99999 \\
\hline $\begin{array}{l}\text { Ability to link directly to existing procurement } \\
\text { systems and transactions }\end{array}$ & 86 & 5.00 & 5.00 & 5.0000 & 99999 \\
\hline $\begin{array}{l}\text { Sharing of supplier intelligence amongst } \\
\text { purchasing entities }\end{array}$ & 86 & 4.00 & 5.00 & 4.6628 & .97553 \\
\hline
\end{tabular}


Sharing of performance information amongst

purchasing entities

\begin{tabular}{|l|l|l|l|l|}
86 & 4.00 & 5.00 & 4.6628 & .97553 \\
86 & 4.00 & 5.00 & 4.6628 & .97553 \\
86 & 4.00 & 5.00 & 4.6628 & .97553 \\
86 & 5.00 & 5.00 & 5.0000 & .99999 \\
86 & & & & \\
\hline
\end{tabular}

Reduction in the risk of collusion between suppliers

Automated audit trails that will provide a record of

who did what, when and why, which will reduce

the possibility of corrupt practices

Improved and more-timely procurement statistics

allowing government to demonstrate how it is

spending tax payer's money

Valid N (listwise)

Source: Field Data 2018

Table 10 sought to determine the respondents` level of agreement or disagreement with the above statements relating to information technology as a factor which affect eprocurement implementation within Kigali city, from the findings majority of the respondents were strongly and agree that Improved and more-timely procurement statistics allowing government to demonstrate how it is spending tax payer's money; Easy authentication of suppliers; Adopt the most appropriate method and approach for procuring the software; Sharing of performance information amongst purchasing entities; Ability to facilitate spend analysis i.e. who is buying what, for how much, when and from whom, through the commodity coding of all purchases; Ability to link directly to existing procurement systems and transactions; Increase customer convenience; Ability to link directly to existing procurement systems and transactions; The procurement process is efficient; Easy and improved records management; Transparency in the supply chain; Sharing of supplier intelligence amongst purchasing entities; Sharing of performance information amongst purchasing entities; Reduction in the risk of collusion between suppliers; Automated audit trails that will provide a record of who did what, when and why, which will reduce the possibility of corrupt practices with the mean varies from 4.3256 to 5.0000 revealed extremely positive and the standard deviation varies from 0.97134 and 0.99999 which shows a positive relationship and a strong concentration among the respondents. While Use of restricted and single source tendering methods; Increase customization online and Request for proposals is done on time with the mean of 4.0000 revealed positive and the standard deviation of 0.88888 which shows concentrated responses from the respondents.

The researcher concludes that E-Procurement has been widely described as using electronic means (the internet, web, e-mail) to buy products and services over the internet. It involves electronic ordering, bidding and rendering via portals, extranets, private platforms, marketplaces. It can also involve the use of purchasing cards, reverse auctions, and/or integrated automatic procurement systems to facilitate, the corporate buying process. Public entities are increasingly using information technology to carry out or support aspects of their business. This means that public entities need to procure information technology. Public entities are also increasingly using information technology to procure other goods and services. A public entity that implements e-procurement systems should ensure that any new procedures that are established meet the same legal and policy obligations that govern all government procurement. In addition, a public entity will need to ensure that it adopts additional policies and standards covering the different procedures and risks associated with e-procurement.

Current use of IT in procurement is the most important general procurement goal which examined the reduction of the purchasing price and the total cost of procurement. Great importance is also attached to internal process optimization. The highest priority for most of the companies in the use of information technology is for central coordination and 
demand aggregation. The priority of IT should be to provide support in the creation of process efficiency and cost / expenditure transparency as well as achieving reductions in the purchasing price. For more than three quarters of the study participants which makes an important contribution to successfully carrying out the procurement function. In addition, expectations of the instruments used are almost all met for a large proportion of the procurement organizations.

\section{Supplier capacity on Implementation of E-procurement in Kigali City}

E-procurement allows buyers to automate transactions and focus on more strategic activities and the use of electronic technologies to streamline and enable the procurement activities of an organization's E-procurement solutions contribute to a better organizational performance, allowing reductions in cost and time when ordering from suppliers, and helping to achieve a well-integrated supply chain with the objective of reaching the market as quickly as possible.

Table 7. Capacity of Supplier on Implementation of E-procurement

\begin{tabular}{|c|c|c|c|c|c|}
\hline Statements & $\mathbf{N}$ & $\begin{array}{l}\text { Mini } \\
\text { mum }\end{array}$ & $\begin{array}{l}\text { Maxi } \\
\text { mum }\end{array}$ & Mean & $\begin{array}{c}\text { Std. } \\
\text { Deviation }\end{array}$ \\
\hline $\begin{array}{l}\text { Reduction in procurement costs that provide new } \\
\text { opportunities by opening the possibility to compete } \\
\text { for business }\end{array}$ & 86 & 4.00 & 5.00 & 4.6628 & .97553 \\
\hline $\begin{array}{l}\text { Financial savings in government procurement costs } \\
\text { will reduce government expenditure and thereby } \\
\text { reduce the need to raise taxes }\end{array}$ & 86 & 4.00 & 5.00 & 4.3256 & .89734 \\
\hline $\begin{array}{l}\text { Under spending on asset maintenance which leads } \\
\text { to the assets' has lower economic productivity }\end{array}$ & 86 & 4.00 & 5.00 & 4.3256 & 89734 \\
\hline Reduction in cost of procurement & 86 & 4.00 & 5.00 & 4.6744 & .97766 \\
\hline Under spending on capital & 86 & 4.00 & 5.00 & 4.3372 & .89755 \\
\hline There is reduction in lead time & 86 & 2.00 & 5.00 & 3.9884 & .62659 \\
\hline $\begin{array}{l}\text { Carefully assess financial risks associated with } \\
\text { transaction fee based models as they are only viable } \\
\text { with the right combination of volumes of } \\
\text { procurement transactions and affordable levels of } \\
\text { fees } \\
\text { Valid N (listwise) }\end{array}$ & 86 & 4.00 & 5.00 & 4.3372 & .89755 \\
\hline
\end{tabular}

Source: Field Data 2018

Table 11 sought to determine the respondents` level of agreement or disagreement with the above statements relating to supplier capacity as the factors which affect e-procurement implementation within Kigali city, from the findings majority of the respondents were strongly and agree that Reduction in procurement costs that provide new opportunities by opening the possibility to compete for business; Carefully assess financial risks associated with transaction fee based models as they are only viable with the right combination of volumes of procurement transactions and affordable levels of fees; Financial savings in government procurement costs will reduce government expenditure and thereby reduce the need to raise taxes; Under spending on asset maintenance which leads to the assets' has lower economic productivity; Reduction in cost of procurement and Under spending on capital with the mean varies from 4.3256 to 4.6744 revealed extremely positive and the standard deviation varies from 0.89734 and 0.97553 which shows a positive relationship and a strong concentration among the respondents. While there is reduction in lead time with the mean of 3.9884 revealed positive and the standard deviation of 0.62659 which shows positive relationship. 
The researcher concludes that the capacity of suppliers on responding to the eprocurement adoption into two different ways. The first is moving aggressively to adopt eprocurement technologies, frequently experimenting with various solutions. The second one adopts a more conservative strategy by selectively experiment with technology.

Also an increasing number of public institutions identified electronic purchasing as a priority to e-government. Many implemented or are implementing e-procurement systems. The adoption of e-procurement in public administration has a huge impact since governments spent large amounts in acquiring materials and services.

In considering how e-procurement impacts buyer-seller relationships that close buyersupplier relationships have a strong positive impact on the implementation of eprocurement. Therefore, while e-procurement may not deliver improved levels of trust, it has been found that e-procurement transactions are more likely to be established first between partners in high trust relationships. In addressing this issue support the view that increased use of e-procurement tend to create more effective customer -supplier relationships over time.

\section{Findings}

Major findings

The general objective of this study is to investigate the factors influencing the implementation of e- procurement in the public institution with a focus on the City of Kigali. The study had a set of specific objectives in which have all been achieved through the field data results.

To determine the influence of top management commitment on the implementation of eprocurement at the City of Kigali

Table 7 sought to determine the respondents` level of agreement or disagreement with the above statements relating to factors affecting e-procurement implementation within Kigali city, from the findings the majority of respondents views agreed and strongly agreed that financial Resources available; the top management support; Ability to link directly to existing systems; the level of Government support; the management support; the size of the firm; National IT infrastructure available to the firm and Competitive pressure from competitors and other stakeholders with the mean from 4.3256 to 4.6628 revealed extremely positive and the standard deviation varies from 0.61402 and 0.97568 which shows a positive relationship.

The researcher concludes that electronic procurement consists of leveraging the purchasing of goods and services using the internet. It is a vital aspect of any overall strategic procurement plan in today's business environment. It includes supply chain automation, strategic sourcing, and supplier rationalization. An electronic solution can significantly reduce cycle times and transaction costs by consolidating the procuring process across all departments, and thus, improve a company's bottom line. Automating the process can free up your time and allow you to better manage your relationships with suppliers in order to create ever-increasing velocity in your supply chain. It has a positive impact on ordering, inventory, returns, billing, and customer service. In the implementation phase the e-Procurement system is delivered in the realization of implemented into the organization and its processes.

Table 8 sought to determine the respondents` level of agreement or disagreement with the above statements relating to top management support as factors affecting eprocurement implementation within Kigali city, from the findings majority of the respondents were strongly and agree that Support the Government of Rwanda's efforts to 
develop online procurement; Undertake an analysis of the current e-procurement practices; Assess financial risks associated with transaction fee based models as they are only viable with the right combination of volumes of procurement transactions and affordable levels of fees; Develop a time-bound roadmap for e-procurement implementation; Development of a realistic and achievable road map; Monitoring and achievable e-procurement using the existing IT systems; Work with tried and tested e-procurement vendors with a proven track record and established technology; Implementation of a simple e-notification and etendering system and a separate procurement management information system and Apply a comprehensive e-procurement Strategy with the mean varies from 4.3256 to 4.6628 revealed extremely positive and the standard deviation varies from 0.87134 and 0.97934 which shows a positive relationship and a strong concentration among the respondents. On the other hand Technical solutions on the e-procurement implementation with the mean of 3.9884 revealed positive and standard deviation of 0.62659 which shows a positive relationship.

The researcher concludes that management input on the course of action is not enough to implement but also needs the staff commitment in the implementation of e-procurement. In line with the interviewer which agreed with the findings that management support provides the orientation on the implementation of e-procurement as well as they help on increasing the skills to succeed; the organization must procure middle-management support who should work hand in hand with the top management during the e-procurement implementation.

To examine how staff training influences implementation of e-procurement in the in the Kigali City

Table 9 sought to determine the respondents` level of agreement or disagreement with the above statements relating to top management support as factors affecting e-procurement implementation within Kigali city, from the findings majority of the respondents were strongly and agree that Ability to short list using supplier sourcing information and performance; Increased confidence in supplier selection by procurement personnel; Reduction in the number of complaints and protests submitted to the Independent Procurement Review Panel; Provide visibility on the overdependence of suppliers or to track unusual procurement patterns that require investigation; Reduction in the time it takes to prepare and publish procurement notices and request for tenders; Reduction in time taken to evaluate bids; Reduction in time taken for bidders to complete and submit tenders; Improvements to procurement planning and demand led intelligence; Improved knowledge capacity and capability of procurement personnel and Reduction in time for the procurement life cycle thereby resulting in a reduction in transaction costs with the mean varies from 4.3372 to 4.6744 revealed extremely positive and the standard deviation varies from 0.87582 and 0.97934 which shows a positive relationship and a strong concentration among the respondents.

The researcher concludes that staff training may improve employee performance the employee who receives the necessary training is more able to perform in their job. The training will give the employee a greater understanding of their responsibilities within their role, and in turn build their confidence. This confidence will enhance their overall performance and this can only benefit the company. Employees who are competent and on top of changing industry standards help your company hold a position as a leader and strong competitor within the industry.

It is in the same line that improved employee satisfaction and morale the investment in training that a company makes shows employees that they are valued. The training creates 
a supportive workplace. Employees may gain access to training they wouldn't have otherwise known about or sought out themselves. Employees who feel appreciated and challenged through training opportunities may feel more satisfaction toward their jobs.

Staff training addressing weaknesses most employees will have some weaknesses in their workplace skills. A training program allows you to strengthen those skills that each employee needs to improve. A development program brings all employees to a higher level so they all have similar skills and knowledge. This helps reduce any weak links within the company who rely heavily on others to complete basic work tasks. Providing the necessary training creates an overall knowledgeable staff with employees who can take over for one another as needed, work on teams or work independently without constant help and supervision from others.

To establish the influence of information technology infrastructure on implementation of eprocurement in the Kigali City

Table 10 sought to determine the respondents` level of agreement or disagreement with the above statements relating to information technology as a factor which affect e-procurement implementation within Kigali city, from the findings majority of the respondents were strongly and agree that Improved and more-timely procurement statistics allowing government to demonstrate how it is spending tax payer's money; Easy authentication of suppliers; Adopt the most appropriate method and approach for procuring the software; Sharing of performance information amongst purchasing entities; Ability to facilitate spend analysis i.e. who is buying what, for how much, when and from whom, through the commodity coding of all purchases; Ability to link directly to existing procurement systems and transactions; Increase customer convenience; Ability to link directly to existing procurement systems and transactions; The procurement process is efficient; Easy and improved records management; Transparency in the supply chain; Sharing of supplier intelligence amongst purchasing entities; Sharing of performance information amongst purchasing entities; Reduction in the risk of collusion between suppliers; Automated audit trails that will provide a record of who did what, when and why, which will reduce the possibility of corrupt practices with the mean varies from 4.3256 to 5.0000 revealed extremely positive and the standard deviation varies from 0.97134 and 0.99999 which shows a positive relationship and a strong concentration among the respondents. While Use of restricted and single source tendering methods; Increase customization online and Request for proposals is done on time with the mean of 4.0000 revealed positive and the standard deviation of 0.88888 which shows concentrated responses from the respondents.

The researcher concludes that E-Procurement has been widely described as using electronic means (the internet, web, e-mail) to buy products and services over the internet. It involves electronic ordering, bidding and rendering via portals, extranets, private platforms, marketplaces. It can also involve the use of purchasing cards, reverse auctions, and/or integrated automatic procurement systems to facilitate, the corporate buying process. Public entities are increasingly using information technology to carry out or support aspects of their business. This means that public entities need to procure information technology. Public entities are also increasingly using information technology to procure other goods and services. A public entity that implements e-procurement systems should ensure that any new procedures that are established meet the same legal and policy obligations that govern all government procurement. In addition, a public entity will need to ensure that it adopts additional policies and standards covering the different procedures and risks associated with e-procurement. 
Current use of IT in procurement is the most important general procurement goal which examined the reduction of the purchasing price and the total cost of procurement. Great importance is also attached to internal process optimization. The highest priority for most of the companies in the use of information technology is for central coordination and demand aggregation. The priority of IT should be to provide support in the creation of process efficiency and cost / expenditure transparency as well as achieving reductions in the purchasing price. For more than three quarters of the study participants which makes an important contribution to successfully carrying out the procurement function. In addition, expectations of the instruments used are almost all met for a large proportion of the procurement organizations.

To determine the influence of supplier capacity on implementation of e-procurement in the Kigali City

Table 11 sought to determine the respondents` level of agreement or disagreement with the above statements relating to supplier capacity as the factors which affect e-procurement implementation within Kigali city, from the findings majority of the respondents were strongly and agree that Reduction in procurement costs that provide new opportunities by opening the possibility to compete for business; Carefully assess financial risks associated with transaction fee based models as they are only viable with the right combination of volumes of procurement transactions and affordable levels of fees; Financial savings in government procurement costs will reduce government expenditure and thereby reduce the need to raise taxes; Under spending on asset maintenance which leads to the assets' has lower economic productivity; Reduction in cost of procurement and Under spending on capital with the mean varies from 4.3256 to 4.6744 revealed extremely positive and the standard deviation varies from 0.89734 and 0.97553 which shows a positive relationship and a strong concentration among the respondents. While there is reduction in lead time with the mean of 3.9884 revealed positive and the standard deviation of 0.62659 which shows positive relationship.

The researcher concludes that the capacity of suppliers on responding to the eprocurement adoption into two different ways. The first is moving aggressively to adopt eprocurement technologies, frequently experimenting with various solutions. The second one adopts a more conservative strategy by selectively experiment with technology.

Also an increasing number of public institutions identified electronic purchasing as a priority to e-government. Many implemented or are implementing e-procurement systems. The adoption of e-procurement in public administration has a huge impact since governments spent large amounts in acquiring materials and services.

In considering how e-procurement impacts buyer-seller relationships that close buyersupplier relationships have a strong positive impact on the implementation of eprocurement. Therefore, while e-procurement may not deliver improved levels of trust, it has been found that e-procurement transactions are more likely to be established first between partners in high trust relationships. In addressing this issue support the view that increased use of e-procurement tend to create more effective customer -supplier relationships over time.

\section{CONCLUSION}

The study entitled "factors influencing e-procurement implementation" was conducted within Kigali City as a case study. The objectives of this research were: to determine the influence of top management commitment on the implementation of e-procurement at the City of Kigali; to examine how staff training influences implementation of e-procurement 
in the in the City of Kigali; to establish the influence of information technology infrastructure on implementation of e-procurement in the City of Kigali and to determine the influence of supplier capacity on implementation of e-procurement in the City of Kigali.

Primary and Secondary data were used in methods of data collection. The analysis and interpretation of the data were made by researcher in line with the research objectives using the Statistical Package of the Social Sciences (SPSS) as the scientific tool.

Generally, it has been funded that many organizations in the world are more registered dismal supply chain performance in terms of partner relationship, information sharing and supply chain integration within supply chain system because of the inefficient and unsustainable procurement procedures as witnessed in the Kigali city. These have led to firms putting emphasis on e-procurement.

Finally, the researcher came to confirm that the factors affecting e-procurement implementation are: top management influence, information technology, staff training and supplier capacity. The fact that each of the e-procurement practices has been adapted to a large extent is step in the right direction for the state corporations since it implies that corporations are not only more receptive and agile but also keen to enhance their competitiveness in the global economy now more than ever before. The challenges identified in the study on the other hand shed light on the critical success factors that need to be put in place to ensure that the e-procurement policy is successful at least in the medium-term.

The following conclusion was made based on the analysis of the data in this study. First the analysis of E-procurement implementation related to the public institutions. Therefore it is important to conclude that majority of the respondents agrees top management commitment, IT influences; staff training and supplier capacity influence the implementation of E-procurement. This implies that staff and management skill is a major aspect to implementation of e-procurement, both the buyer and the purchaser need to have e-procurement skills for them to operate the system. For E-procurement to be implemented successfully there must be a very good integration between the buyers and the sellers, even when the buyer has an e-procurement system and the supplier does not have then implementation of e-procurement cannot be successful. Systems like electronic data interchange assist in the integration between the buyer and the seller. Most of the infrastructure associated with e-procurement is very expensive and as a result they do not have the financial muscles to purchase such systems hence affecting implementation of Eprocurement. The relationship between E-procurement implementation and skills, supplier, and IT infrastructure is strong.

From the study some recommendations were suggested for improvement or practice and for further research by scholars or readers. These suggestions for improvement are aimed at improving the effectiveness of operations of the impact positively on performance of the public institutions. The Public institutions recruitment department/human resource department should ensure that the staffs recruited are qualified and competent to be able to ensure implementation of e-procurement. Especially procurement staff should be knowledgeable in e-procurement practices and requirements they should have the best skills and expertise on the systems. The government should give subsidies that encourage the Public institutions to implement E-procurement, for example they can offer trainings on the use of e-procurement systems at a cost that is affordable to most people working in the Public institutions, through this most people can afford the trainings hence they will be empowered with the knowledge. The Public institutions buyers and seller should work together and develop very close relationships with each other through this they can be able 
to benefit from one other. Both the buyer and the supplier will be able to access skills, knowledge, expertise and technology from each other hence together they can develop a system that integrates their transactions. The cost of E-procurement infrastructure is very expensive. Most of the E-procurement systems have different licenses, the more the licenses the more expensive it is. Public institutions can purchase license for few user hence they will be able to implement E-procurement at a very low cost.

\section{REFERENCES}

Abagna James Azanlerigu \& Akay,Emmanuel,. (2015) Prospects and Challenges of EAcademic Journal of Procurement and Supply Chain Management Volume 2, Issue adoption and use of e-procurement technology models", European Management Journal, Almarabeh, Tamara \& AbuAli, Amer (2010). 'A General Framework for E-Government:

AlRashidi, Hajed (2010). Examining Internal Challenges to E-Government Implementation from Anandarajan, M., Igbaria, M. \& Anakwe, U. (2002). IT acceptance in a lessdeveloped country: and Uganda", OECD Development Centre Working Paper No. 208, March 2003. and transitional nations. Information Management \& Computer Security', Vol 16,

Angeles, R., Nath, R. (2007), "Business-to-business e-procurement: success factors Arrowsmith, S., Lineralli, J., \& Wallace, D. (2000), Regulating Public Procurement: Auriol, E., Picard, P.M. (2009), "Government outsourcing: public contracting with Beth, S., Burt, D.N., Copacino, W., Gopal, Ch., Lee, H.L., Lynch, R.P., Morris S., 2003, Brun, A., Corti, D. \& Cozzini, S. (2004), "Value assessment of e-procurement projects: Content Analysis of Government Websites. Electro'. J. e-Govern., Vol. 2, no. 1, pp.

Corini, J. (2000), "Integrating e-procurement and strategic sourcing", Supply Chain corporations in Kenya: A case of Utalii College'. Journal published by InternationalCorruption and poverty: Lessons from Kenya case studies. Nairobi: African Center

Dada, D. (2006). The Failure of E-government in Developing Countries: A Literature Review. Heeks, R. (2006). 'Implementing and Managing e-government'. Sage Publications, pp. 293 The

Davila, A., Gupta, M., Palmer, R. (2003), "Moving procurement systems to the internet: the

De Boer, L., Harink, J., Heijboer, G. (2002), "A conceptual model for assessing the impact of Definition Maturity Challenges, Opportunities, and Success'. European Journal of and political rationality, Proceedings of the 37 Hawaii

Gattorna, J., 2006, Living Supply Chains, Prentice Hall, London Government of Kenya Global Purchasing \& Supply Chain Strategies

Goerdeler, A. (2003), Electronic Public Procurement in Germany. Business Briefing: government purchasing. International Journal of Production Economics, 90, pp 79-

Gunasekeran, A. and Ngai, E. (2008), "Adoption of e-procurement in Hong Kong: an Henriksen, H.Z., Mahnke, V. and Hansen, J.M., (2004). Public eProcurement adoption:

Huber, B., Sweeney, E. \& Smyth, A. (2004), "Purchasing consortia and electronic markets IADIS Conference on e-Society', Lisbon, Portugal.

Ikiara, G., (2000) "Corruption in procurement", in Mullei, A., (ed). The link between procedures and critical success factors'. European Journal of Industrial Marketing Management, No. 32, pp. 251-63.

Kaaya J (2004). 'Implementing e-Government Services in East Africa: Assessing Status through

Kheng, C.B. \& Al-Hawandeh, S. (2002), “The adoption of electronic procurement in 
Kothari, T., Hu, C. and Roehl, W. (2005), "E-procurement: an emerging tool for the hotel Luvuye, Mkululi Mgidlana, (2013) factors affecting adoption of e-procurement technologies Management, Vol. 13 pp.294-303.

Mandal, P., \& Gunasekaran, A. (2003). 'Issues in implementing ERP: A case study'. European Markets, Vol. 14 No. 4, pp. 284-94.Masola Publishers.

Metoh, Isaac Kipyego (2006). Factors affecting implementation of electronic

Middleton, M. R., (2007). 'Approaches to evaluation of websites for public sector services.

Min, H. \& Galle, W. (2002). E-purchasing: profiles of adopters and nonadopters. motivational factor perspective. International Journal of Information

Mutula M. S. (2008). 'Comparison of sub-Saharan Africa's e-government status with developed National and International

Odhiambo, W., \& Kamau, P. (2003), "Public procurement: Lessons from Kenya, Tanzania of Business Logistics, 17 (1), 23-34. 